\title{
Longevity: Lesson from Model Organisms
}

\author{
Giusi Taormina, Federica Ferrante, Salvatore Vieni, Nello Grassi, Antonio Russo and \\ Mario G. Mirisola *D \\ Dipartimento di Discipline Chirurgiche, Oncologiche e Stomatologiche, Università di Palermo, \\ Via del Vespro 129, 90100 Palermo, Italy \\ * Correspondence: mario.mirisola@unipa.it
}

Received: 10 April 2019; Accepted: 2 July 2019; Published: 9 July 2019 updates

\begin{abstract}
Research on longevity and healthy aging promises to increase our lifespan and decrease the burden of degenerative diseases with important social and economic effects. Many aging theories have been proposed, and important aging pathways have been discovered. Model organisms have had a crucial role in this process because of their short lifespan, cheap maintenance, and manipulation possibilities. Yeasts, worms, fruit flies, or mammalian models such as mice, monkeys, and recently, dogs, have helped shed light on aging processes. Genes and molecular mechanisms that were found to be critical in simple eukaryotic cells and species have been confirmed in humans mainly by the functional analysis of mammalian orthologues. Here, we review conserved aging mechanisms discovered in different model systems that are implicated in human longevity as well and that could be the target of anti-aging interventions in human.
\end{abstract}

Keywords: model systems; aging; signal transduction; molecular senescence

\section{Introduction}

Aging is considered a natural and unavoidable "side effect" of life in spite of the observation that life span can vary greatly between species and individuals. Researchers have developed many theories on the cause of aging, but none of them prevailed. George Williams, an undisputed leader of the field, proposed that natural selection fixes alleles in a population for their positive contribution to fitness early in life, but that the selected alleles become deleterious later in life [1]. Around this idea, he developed the antagonistic pleiotropy theory. According to this proposal, aging is the result of (a) casual selection of late-acting deleterious alleles because of their advantage early in life and (b) the incapacity of natural selection to filter the late-acting detrimental effect of these alleles. Corollary to this theory is that mutations that are capable of increasing the life span must cause a disadvantage or a reduced fitness during the early stages of life. Many mutations that are capable of increasing the life span of different model systems confirmed this prediction, but the existence of long-lived mutants, such as the yeast Ras 2 or the C. elegans daf- 2 that grow and reproduce at a normal rate [2], suggests that extended life doesn't imply a reproductive or growth rate fitness cost. However, these observation are made in laboratory conditions; therefore, we cannot exclude that these mutants could also show a reduced fitness, but only in the wild.

The disposable soma theory proposes aging as a stochastic process driven by the progressive accumulation of molecular damages within somatic cell lines. This damaging force can be counterbalanced by repair systems that tend to maintain the cellular status quo at some energetic cost. Therefore, the aging rate, which profoundly differs between species, is inversely associated with the amount of energy used for somatic maintenance. According to this theory, periods of nutrients shortage forced organisms to balance the energy used for germ line maintenance as well as reproduction and somatic maintenance [3]. Programmed longevity theory has been proposed as an alternative [4]. It proposes that the healthy portion of life span is programmed to increase the fitness. The aging rate 
wouldn't be regulated by an energy-based trade-off between reproduction and longevity, but each species reaches an evolutionary stable strategy. According to this theory, most longevity-extending mutations will cause a trade-off, but some won't.

However, there is the possibility that the group instead of the individual is the object of evolution. According to this theory, fitness is affected by either "group competition", "individual competition", or both, depending on the conditions encountered. The advantage of the single individual is positively selected only if it also confers a group advantage. Mathematical simulations and experimental evidences suggest that at least in S. cerevisiae, aging under certain conditions can be programmed, and an altruistic life span extension of the individual can provoke the extinction of the group [4].

None of these theories prevailed so far, which was probably because the complex forces of evolution cannot be simplified by a single scheme. Evolution may be the result of multi-level selection where individual fitness or group fitness are preferred, depending on ecological niche and population density.

Model systems have been widely used to confirm these theories. Their advantage relies on reduced costs, easy maintenance in a laboratory facility, and affordable but rigorous manipulation tools. In general, the simpler the organism we use as a model, the greater these advantages. The short life span of simple organisms is another key advantage of model systems in aging research (Figure 1), which allows both parallel and serial experiments to be performed in reasonable time. In addition, rigorous genetic experiments can be performed in simple eukaryotes using the powerful possibilities of modern molecular genetics, which permit simultaneously screening multiple congenic, or even in some models such as yeasts or isogenic individuals at relatively low cost. The other side of the scale is that some of the simpler systems cannot model alone all the aging phenotypes (e.g., immunosenescence can't be modeled by yeasts). It is not surprising that, as in many other science fields, biogerontologists thus widely take advantage from the usage of multiple model organisms to explore their theories. In addition, ethical issues are of course much more limited in simple model organisms making Saccharomyces cerevisiae, Caenorhabditis elegans, Drosophila melanogaster, and Mus musculus the most popular model systems used in aging research. Canis lupus familiaris is becoming an interesting alternative to those model systems because, even though it has a similar ethical constraint to that of humans, massive breed selection offer interesting genetic opportunities. We will describe below the genes and pathways discovered thanks to these organisms that have shed light on possible aging mechanisms in humans.

\section{The Simplest Eukaryotic Model: Yeast Cells}

Yeast has played a critical role in revealing the molecular genetics of many basic cellular processes such as the cell cycle [5], protein folding [6], intracellular trafficking [7,8], and many others. A short generation time, easy and cheap lab setups, powerful genetic approaches, and high-throughput methodologies [9] are some of the attractive factors of this simple unicellular eukaryote. Genome similarities (homologue and orthologue genes) between this very simple organism and mammalians or even humans are surprisingly high, suggesting that this organism can be an effective model of human diseases [10-12]. Two different paradigms of aging exist in yeast: replicative life span (RLS) and chronological life span (CLS) [13]. The first one measures the replicative potential of individual cells. Single cells can in fact be monitored for their ability to generate new cells. Almost 60 years ago, Robert K. Mortimer used this characteristic to count the number of cell divisions obtained from a single cell [14]. In this protocol, the emerging bud (daughter cell) is carefully removed by micromanipulation as it appears until the mother cell stops dividing. The second paradigm (CLS) measures instead the survival of a cellular population in the post-mitotic, non-dividing phase [15]. Thus, the yeast RLS resembles the Hayflick limit observed in cultured mammalian cells, measuring essentially the doubling ability of cultured cells, while the CLS models better the ability to survive and retain the doubling potential of post-mitotic tissues. It is interesting to note that in spite of the clear differences of the two paradigms used to summarize aging in yeast, some pathways such as Ras-PKA or Tor-Sch9 have a consistent role in CLS and RLS [13,16], while others do not (e.g., 
Sir2 [17]). The yeast life span is doubled through deletion of the gene encoding the small G-protein Ras2, showing a contemporary higher resistance to multiple stresses [18,19]. Ras proteins are molecular switches that can cycle between the on-off state, which correspond to the GTP-bound and GDP-bound, respectively [20]. Mutations on the human orthologue of the yeast Ras are found in $35 \%$ of human cancers. The amount of the Ras on-state molecules is dependent on the availability of sugars [21]. Two different pathways are known to be dependent on Ras2 activation in yeast: protein kinase A (PKA) and Mitogen-activated protein kinase (MAPK). Many data suggest a major role of the PKA pathway as a longevity regulator [22]. Msn2/Msn4, two key stress resistance transcription factors, are in fact inhibited by kinase A activity, and Msn2/4 deletion reverts the phenotype observed with Ras2 deletion. In addition, mutations affecting adenylate cyclase, an activator of the kinase A pathway, also increased the survival of yeast cells, confirming the role of the PKA pathway as a major Ras-dependent pathway relevant to the aging processes. PKA activation leads to Rim15 inhibition which, in turn, positively regulates the transcription factors Gis1 [23], Msn2, and Msn4, whose function is to bind respectively the PDS (post-diauxic shift) and STRE (STress Responsive Element) sequences activating the expression of genes involved in survival and stress response such as heat shock proteins, the cytoplasmic catalase, and the two superoxide dismutase (SOD1, SOD2) [24,25], or in DNA repair such as the DDR2 gene [26].

A selection of stress-resistant mutants obtained by transposon mutagenesis was evaluated by chronological life span to isolate long-lived mutants. In this study, the Sch9-Tor pathway emerged as another pro-aging pathway $[27,28]$. Sch9 is a serine/threonine protein kinase that is homologous to mammalian Akt and S6K. It has been isolated in yeast as a multicopy suppressor of Ras/PKA through the conditional inactivation of the thermosensitive Ras exchange factor allele CDC25ts [29,30]. In addition, the increased G1 length of yeast cells bearing a Sch9 null allele is suppressed by a hyperactive kinase A pathway. These and other data suggest that its function is partly overlapping with the Ras/PKA pathway. The down-regulation of both signaling pathways obtained by specific nutrients depletion results in the greater expression of genes involved in resistance to stresses [31]. The observation that SOD2 expression levels doubles in ras $2 \Delta$ strains suggests that oxidative stress is a major component of this response [32]. In addition, overactivation of the transcription factors that respond to thermal (HSF1) and oxidative stresses (YAP1) increases survival [33,34]. In spite of these observations, the over-expression of superoxide dismutases and catalases alone does not allow the survival levels obtained by the deletion of RAS2 and SCH9, suggesting that modulation of oxidative stress is not the only mechanism involved in longevity regulation. In addition, despite the aforementioned functional overlap between the Ras and Sch9 pathways, the simultaneous deletion of RAS2 and SCH9 has greater effect than their respective individual deletions. It is important to notice once again that the mediators that are part of these pro-aging cell pathways find their functional or structural orthologues in higher eukaryotes, and it has been confirmed that the mechanisms described are conserved from yeast to mammals. In addition, it has been observed that in all organisms, these pathways are influenced by nutrients, either directly or through insulin/insulin-like growth factor-1 (IGF-1) and growth hormone (GH) in multicellular eukaryotes [35-37].

\section{Caenorabtidis elegans}

Caenorhabditis elegans has been established as a model organism in 1965 by Sidney Brenner. This small size (1.5-mm long adult) soil nematode has great potential for genetic analysis, is easy and cheap at laboratory cultivation, and has a short life cycle: the generation time is only three to five days, and the life span is two to three weeks. C. elegans can inbreed by self-fertilization (hermaphrodite). Alternatively, hermaphrodites can cross with males (a possibility that is otherwise known only in plant genetics where selfing and crossing can be manipulated at will). Other key features are the anatomical simplicity ( $<1000$ cells) and the small genome. The latter is about $101-\mathrm{Mbp}$ long, consists of six chromosomes, and contains 19,000 genes, of which 50\% are conserved in the human genome. The animal body is transparent, which is a characteristic that allows the tracking of cells in vivo over time, and the fluorescent visualization of tagged proteins. It can be cultivated on agar plates or in 
liquid media; therefore it is a good system for a wide variety of high-throughput manipulations. In addition, the researchers take advantage of its powerful and continuously expanding genetic and imaging possibilities [38,39]. First, a multicellular organism is completely sequenced, revealing a conservation of $\sim 80 \%$ of its proteins with vertebrates [40]. RNA interference (RNAi) was the most commonly used approach to address gene function; however, tissue-specific knockdowns have recently been developed [41]. Another reason for its wide usage as a model system is that simple phenotypes can be observed, easing the analysis of most genetic screens.

Many key factors that are capable of regulating longevity have been discovered using this model organism [42,43]. In 1993, it was demonstrated that mutations at the daf-2 locus, which encodes an ortholog of the insulin/IGF1 receptor, doubles the life span of the animal [44-46]. Further molecular characterization revealed that the life-span extension observed with defective daf- 2 alleles required the activity of the daf- 16 gene product [44]. The latter is a transcription factor of the FOXO (forkhead box transcription factor $\mathrm{O}$ ) family, giving the first example of transcriptionally regulated aging modulation [47]. The FOXO family is an evolutionary conserved group of transcription factors that target the protein kinase Akt. In the presence of growth stimuli, FOXO proteins are first exported from the nucleus to the cytoplasm, and then degraded via the ubiquitin-proteasome pathway. On the contrary, in the absence of growth stimuli, FOXO proteins are imported to the nucleus, where they up-regulate a group of target genes, ultimately promoting cell cycle arrest, stress resistance, or apoptosis. Stress stimuli also trigger the relocalization of FOXO factors into the nucleus, thus allowing an adaptive response to stress stimuli. Additional studies identified the PI-3 kinase signaling pathway as the downstream molecular cascade target of the DAF-2 receptor, provoking the nuclear localization of the mentioned DAF-16 transcription factor [48-50]. HSF1, the C. elegans orthologue of the heat shock transcription factor, plays a critical role in the DAF-2 observed regulation of longevity. It has also been demonstrated that HSF-1 is capable of increasing the life span of DAF-2 pathway mutants, suggesting that heat shock proteins may have a pleiotropic role on pathways other than the daf-2 molecular cascade [51]. At the same time, mutations in daf-18, which is a homolog of PTEN (Phosphatase and tensin homolog) phosphatase that normally negatively regulates the insulin-dependent signal, suppress the increased survival due to mutations on DAF-2 and age- 1 loci $[52,53]$. The latter codes the C. elegans catalytic subunit of the phosphatidylinositol-3-OH kinase (PI(3)K), whose impairment triggers constitutive Dauer status (the larva goes into a type of stasis and can survive harsh conditions), and increases life span and stress resistance. The lengthening of the survival of these mutants has been related to their increased resistance to oxidative stress; in fact, DAF-2 mutants express high levels of antioxidant enzymes such as catalase and superoxide dismutase, as well as low levels of free radicals. Mutants at the age- 1 locus prevent the age-related decrease of catalase levels [54]. Other proteins that have been identified as important for longevity in nematode include the protein kinase phosphatidylinositol-dependent 1 (PDK1), the kinase Akt, and the mitochondrial enzymes $\mathrm{Clk}$ involved in ubichinone synthesis. In particular, the reduction in Clk-1 function produces smaller worms that live $15-30 \%$ longer than wild types, which is probably thanks to a decrease in basal metabolism and oxidative damage [55].

\section{Drosophila melanogaster}

Drosophila melanogaster has a 100 year-long history as an important model organism for studies on genetics and molecular biology. In 1908, Thomas Hunt Morgan was the first to use Drosophila as a model organism, demonstrating that genes are located on chromosomes. The fruit fly has also been the first organism for which a genetic map was obtained, thanks to Alfred Sturtevant and Calvin B. Bridges. Drosophila melanogaster has a generation time of 10-14 days and shows a high rate of reproduction. Large numbers of flies can easily be cultivated. Maintenance is quite simple and cost-effective. Drosophila's genome is very simple: four pairs of chromosomes, 13,000 genes, and about $170 \mathrm{Mbp}$; it is about 20-fold smaller than a typical mammalian genome, but in spite of that, it encodes approximately the same number of gene families, thus making it easier to study 
gene function. Furthermore, many pathways, tissues, and organ systems in Drosophila are shared by mammals; approximately $60 \%$ of the genes that are known to be involved in human diseases have functional orthologues in the fruitfly. Thus, Drosophila represents one of the most useful and popular model organisms for research on human diseases. Aging research further benefits from its short life span (4-6 weeks), which allows manipulating and observing several generations while monitoring the effect of drugs, nutrients, genetic manipulation, as well as environmental factors over time. Other advantages are the wide range of tools to modulate gene function (such as mutagenesis screens, RNA interference, and transgene expression in specific stages of life or in selected tissues) and resources (cell lines, clone libraries, antibodies, microarrays, and databases) [56,57].

Studies on Drosophila show that longevity increases as a result of the over-expression of genes involved in stress response such as hsp70 (which encodes the heat shock protein 70), MnSOD (producing the superoxide dismutase), and mei-41 (involved in DNA repair) [58]; meanwhile, the loss of function of the pathway that includes the hormone receptor Dts3 and the insulin receptor (InR), Chico (which is the substrate of InR $[59,60]$ ), and the transcription factor dFOXO, greatly increases the life span [61]. Giannakou and Hwangbo in 2004 demonstrated that the tissue-specific overexpression of FOXO in gut and fat extends the life span, which is likely through the transcriptional repressor aop [62], which shares some targets with FOXO. Among these, Obp99b seems to have a key role, since it is upregulated in a long-lived Drosophila model [63]. mTOR inhibition also by rapamycin administration [64] extends life spans [65], but only in the presence of the s6 kinase $[65,66]$. The life extension by rapamycin treatment also requires an intact autophagy pathway $[64,67]$. Dietary restriction can increase the longevity of D. melanogaster by up to $30 \%$ as well as reduce the reproduction rate [68]. The restricted intake of specific nutrients, particularly proteins, may mediate the benefits as well as alter the macronutrients ratio. Amino acids and some amino acids sensors, such as Gcn2, seem to have a key role in life-span extension by dietary restriction [69].

\section{Mouse}

Domestic mouse is the most widely used mammalian model. Its genome is almost the same size as the human one (2.5 Gbp and 40 chromosomes), and encodes essentially the same number of genes. Most $(85 \%)$ of protein-coding regions of the mouse genome are identical to human genome; in addition, $99 \%$ of the 25,000 genes have a human orthologue. Compared to other model organisms, working with mice is more difficult in every respect. They are bigger, have a generation time of about $8-10$ weeks, and produce, on average, only six to eight young per brood. These numbers are interesting when compared to other mammals, but aren't when compared to simpler model organisms. Colonies of mice are expensive to maintain, and their genetic manipulation is quite difficult. However, unlike the fruit flies and nematodes, mice have an immune system, musculoskeletal apparatus, endocrine system, digestive system, and even nervous system similar to humans both in function and architecture. A fundamental tool to explore the genetics of aging in mammals is the identification of single-gene mutations that increase life span. The first of these was discovered in 1996 studying the Ames dwarf mouse [70]. Ames dwarf mice produce a reduced amount of growth hormone (GH), prolactin, and thyroid-stimulating hormone; they have a recessive point mutation in the Prop1 gene leading to hereditary dwarfism [71]. Prop1 encodes a protein required for the pituitary activation of Pou1f1, which is a member of the POU family of transcription factors implicated in mammalian development [72]. In 1996, Brown-Borg et al., following the life span of 62 Ames dwarf mice, showed a mean life span increased of $49 \%$ and $68 \%$ in males and females respectively, and a maximal life span extension of $20 \%$ and $50 \%$, respectively [70]. This was the first demonstration that a single gene mutation can extend the life span in mammals. The Snell dwarf mouse was described in 1929; it has a recessive spontaneous point mutation in the Pou1f1 gene that causes hereditary dwarfism [73]. Flurkey et al. in 2001 followed the life span of 24 Snell dwarf mice together with 33 normal controls. He discovered that the mean life span was extended in the dwarf group by $48 \%$, and some of the common age-related declines were delayed $[74,75]$. Other studies highlight that 
the dwarf mice have alterations in insulin/IGF-1 signaling: both Ames and Snell dwarf mice have severely reduced circulating levels of insulin, IGF-1, and glucose [76,77]. In addition, the dwarf mice show a slower metabolism [78]. Most of the dwarf mice are also infertile [79], but they display a lower spontaneous mutation frequency [80] and a very low incidence of malignant lesions compared to controls at the time of death [81]. Notably, dwarf mice have reduced levels of DNA and protein oxidation in the liver compared to control mice [82], according to increased levels or activity of catalase and $\mathrm{Cu} / \mathrm{Zn}$ superoxide dismutase in various tissues at different ages $[83,84]$, which makes these mice resistant also to the effects of chemical stressors [85], and shows low levels of reactive oxygen species. However, the importance of oxygen concentration as a driver of protein and DNA damages leading to cellular senescence has recently been challenged [86]. In fact, it has been demonstrated that while lab mice-derived primary fibroblasts are sensitive to oxygen concentration, primary fibroblasts from wild-caught mice are not. In addition, cells from other wild-caught rodents have lower oxygen sensitivity than lab mice-derived cells [86]. This observation underlines the need to use multiple model systems and the necessity, when possible, to confirm the results on wild-caught animals, since the repeated breeding and the laboratory condition of lab animals may trigger unwanted genetic drift.

An example of the results confirmed in multiple systems are the metabolic pathways involved in the aging of Drosophila and C. elegans, which were confirmed in mice thanks to genetic manipulation. Among the genes whose deletion significantly increases the survival of mice, some of the genes involved in stress resistance have been identified, such as for example GPx4, which codes for glutathione peroxidase, and some that are part of the insulin pathway, such as FIRKO (insulin receptor in adipose tissue) [87]. Animals that have mutations in the growth hormone receptor also live longer and show a lower incidence of age-related cognitive impairment and improved insulin sensitivity [88], while those who over-express GH show signs of accelerated aging [77]. Also, female Irs-1 knock-out mice (Irs-1 is the major intracellular effector of insulin) live 32\% longer than the wild-type counterpart. Finally, inhibition of the mTOR (mammalian target of rapamycin) pathway, which was obtained by rapamycin administration through $\mathrm{S6}$ kinase deletion, increases survival and reduces the incidence of age-related diseases, including immune dysfunction and insulin resistance [89]. Inactivation of the PKA pathway also increases survival and causes a reduction of tumor incidence and insulin resistance over time. Another key aging gene in mice is klotho. This protein is a circulating factor that inhibits the intracellular insulin/IGF-1 signaling cascade, but its function is still controversial. Homozygous klotho-deficient mice display a syndrome similar to human progeria and anomalies in different tissues. These mice are short-lived and infertile; they show growth retardation, premature thyme involution, ectopic calcification, skin atrophy, arteriosclerosis, osteoporosis, and pulmonary emphysema [90]. On the other hand, klotho gene over-expression extends mice life span by 20-30\% [91]. Higher levels of klotho are associated with longer life span, reduced atherosclerosis risk, and better hearing than other mouse strains [92]. Some mutants with mutations in DNA maintenance, stability, and repair exhibit premature aging phenotypes. Wrn knock-out mice lightly display characteristics of premature aging, including the contemporaneous deletion of the Terc gene, which encodes the RNA component of the telomerase enzyme, and brings Werner's phenotype [93].

\section{Domestic Dog}

The domestic dog is a very interesting aging model for different reasons. Dogs allow us to observe them in their natural environment while being investigated; notably, they often share lifestyle and sometimes exercise habits with humans. Canine life span can vary greatly [94]. Interestingly, it has been observed that life span inversely correlates with body size. Larger breeds live almost six to seven years, while smaller breeds can reach up to 16 years [95-97]. Dogs share the same diseases with humans, in particular age-related diseases such as congestive heart failure, renal and hepatic disease, sarcopenia, diabetes, obesity, joint disease, neurodegeneration, cataracts, immune-mediated illnesses, and cancer [97-101]. In addition, it is the only species where massive breed selection has led to large numbers of individuals with very small phenotypic and genotypic differences within a specific breed, 
but with very large differences between different breeds. Maybe as a result of this strong selection for specific traits, some pure breeds of dogs are more prone to specific age-related diseases than others [97]. For example, the analysis of cancer incidence in different pure breeds confirmed that larger breeds have a higher incidence of cancer but revealed also that each breed has increased incidence for specific cancer types, suggesting that anatomic differences and genomic differences between breeds can explain these differences. It is also interesting to know that as a companion animal, dogs often share part of their lifestyle with their owners, including physical exercise. At the same time, dogs receive medical treatments from veterinarian specialists during their life as it happens for humans, and that contributes to increase the life span of these companion animals. The domestic dog has a well-annotated genome that was fully sequenced 10 years ago [102-104]. The size of the diploid genome is $4900 \mathrm{Mbp}$, which is organized in 38 pairs of autosomes and two sex chromosomes. Different genetic resources are applied in canine genetic research. Furthermore, genetic pedigrees are registered for many generations [105]. Greer et al. (2007) reported a correlation between body size and longevity. They noticed that smaller members (Chihuahua) live longer than larger members (e.g., Great Dane) [95]. Similar data have been obtained from studies in a murine system in which the IGF/GH axis resulted involved in longevity and body size determination [106]. Notably, circulating IGF-1 levels correlate with the body size of adult dogs; in fact, IGF-1 levels increase with body weight. Therefore, the data is consistent with previous work by Eigenmann et al. (1988), indicating that adult dogs have a high correlation between circulating IGF-1 and adult body size [107]. Furthermore, IGF-1 decreases over time as a function of age [108]. In addition, a reduction of the insulin/insulin-like growth factor-1 (IGF-1) signaling cascade significantly extends life span [109]. Interestingly, Greer et al. described that serum IGF-1 levels decrease at a higher rate in intact females than in spayed females. Similarly, there is a significant difference in the serum IGF-1 levels between neutered and intact males. For both intact males and females, an increase in overall body weight was significantly associated with higher levels of IGF-1. These data suggest relevant hormonal effects on IGF-1 action [104]. Interestingly, Waters et al. (2009) demonstrated that dogs with four years or more of ovarian hormone exposure live longer than ovariectomized dogs [110]. Therefore, higher body weight is related to high level of serum circulating IGF-1, which in turn seems to be deleterious for aging. Accordingly, the maintenance of lean body mass and reduced accumulation of body fat have been associated with attaining a longer than average life span [111]; thus, dog's weight may be more predictive of life span than height, as reported by Greer et al. [95]. A dietary restriction of $25 \%$ has been reported to increase life span by about two years [112,113], improving metabolic health $[114,115]$ and delaying immune senescence in Labrador retrievers maintained in a laboratory environment $[114,115]$. Further studies will be necessary to discriminate as to whether increasing the health and life span after CR in dogs is the effect of weight loss or depends on the down-regulation of pro-aging pathways such as previously demonstrated in simple model organisms such as yeast. Actually, studies carried out by Jimenez et al. suggest that large breed dogs may have higher glycolytic rates, and an increased DNA mutation rate, which could be responsible for their decreased life span compared with small breed dogs, despite reactive oxygen species (ROS) production showing no differences across size and age classes [116]. Likewise, Alexander et al. observed a decline in the heat shock protein 70 response after heat stress with age, suggesting a role of oxidative stress in dog's aging [117].

\section{Non-Human Primates}

The models closest to humans are non-human primates. In fact, the chimpanzee genome has more than $98 \%$ homology with the human genome, while the rhesus monkey (Macaca mulatta) has 93\% DNA homology with the human genome [118,119]. The Macaca mulatta genome is $3146 \mathrm{Mbp}$ and codes 21,000 different proteins [120]; Pan troglodytes, a common chimpanzee, has a 3385-Mbp genome coding for 23,534 proteins. Interestingly, they have a similar inter-individual variability to humans and share eating and sleeping behavior, physiology, neurology, endocrinology, immunology, as well as anatomy [121]. Their average life span ranges from 7 to 30 years depending on the species considered, while the maximum life span 
of the commonly used macaque reaches 40 years, and the chimpanzees can reach up to 65 years [122]. Similarly to humans, monkeys exhibit signs of physical decline and many age-associated diseases, including [123]: sarcopenia [124], osteoporosis [125], cataracts, cardiovascular diseases, and cancer [123]. In fact, the incidence of these diseases is similar to that in humans. Researchers take advantage of two important resources: the Internet Primate Aging Database, which collects data such as body weight and blood chemistry measurements on many non-human primate species during aging, and the Nonhuman Primate Tissue Bank. Another advantage is the possibility to fully control the environment, dietary intake, and medical history. On the other hand, non-human primates require specialized care, have high cost, and require ethical considerations. However, they represent the ideal model to summarize the complex in vivo physiology of human aging. Even though research such as direct manipulation of the monkey genome are not possible for ethical reasons, observational studies and dietary interventions may give us very useful information, especially to validate in the closest to human system what has been previously discovered in simpler organisms. To this purpose, three major studies have been performed in non-human primates to evaluate the efficacy and safety of calorie restriction and aging: one was performed at the University of Maryland [126], one was at NIA (National institute of Aging) [127], and the last one was at the Wisconsin National Primate Research Center [128]. All of them confirmed the benefits of CR on health. The University of Wisconsin study confirmed that CR reduces disease incidence and prolongs life span [129-131], while the NIA study doesn't observe a different survival between CR and control monkeys. Differences in feeding protocol, diet composition, and the timing of $\mathrm{CR}$ onset may explain the observed differences [132]. However, data from both studies suggest that many of the beneficial effects of CR reported in rodents also occur in primate models, thus suggesting a possible role also in human aging [131].

From comparative genetics studies between non-human primates and humans, it is deducible that some of the genetic regulatory processes that are important during development are less subjected to selective pressure and may became adverse later in life [133]. Blalock et al. analyzed gene expression in two major hippocampal subdivisions that are critical for memory/cognitive function in rhesus monkeys, identifying genes that changed expression with aging, and showed that increased gene expression of the glucocorticoid receptor happens with aging in rhesus macaques, linking the age-dependent metabolic syndrome to aging changes in the brain [134]. Epigenetic changes occur during aging in monkeys. In rhesus macaque brains, aging is associated with a global increase in H3K4me2 and H3K4me3 transcriptional activation; in addition, SETD7 and DPY30 (H3K4me2 methyltransferases) show elevated expression [135]. A role in aging has been ascribed to miRNA; in particular, Mohan et al. identified the miR-34a-SIRT1-acetylp65 axis as a potential mediator of "inflammaging" in the intestine [136].

\section{Discussion}

Humans are not an easy-to-study system both for ethical as well as for practical reasons, and have required the support of simpler organisms to model their physiology and pathology. Epidemiology, one of the most used approaches to investigate humans, is the branch of science that tries to count how often a certain pathology occurs in different population groups, hopefully identifying the risk or protective factors against certain pathologies. It is an essential methodology to study humans, but can fall short because it often requires a very large cohort of people, is normally very time and budget consuming, and can potentially be affected by many confounding factors. Clinical trials often use small groups of people to be cost effective and test specific hypotheses ranging from the safety/effectiveness of selected drugs to specific devices. Of course, obvious ethical as well as practical issues limit the potential of this approach in humans. Therefore, although both approaches are essential for the understanding of human physiology and pathology, they unlikely may suggest alone new branches of science or help to develop breakthrough ideas [137]. On the other hand, human genetics has been very successful, and revealed the genetic cause of more than 6000 monogenic diseases in humans, but it is hard to imagine the development of this science without the seminal discoveries 
in plants, fruitfly, fungi, etc., also in humans. The identification of genes and pathways relevant for human longevity has acquired deep advantages from model systems and discoveries, which can be grouped in four functional categories:

- Genes related to stress resistance: their role in longevity has first been demonstrated in many different model systems $[18,24,25,32-34,51,54,58,82-85]$ and eventually confirmed in centenarians who show a low degree of oxidative stress as well as high antioxidant protection [138,139]. A high level of oxidative stress is also an important risk factor of other age-related diseases such as hypertension, atherosclerosis, and diabetes. SNP (single nucleotide polymorphisms) studies have identified Tp53, coding for tumor suppressor p53 [140-142], EXO1 [143], GPX1 (glutathione peroxidase1) [144], SOD2 (manganese superoxide dismutase) [145], heat shock proteins genes HSPA1A, HSPA1B, and HSPA1L [146-148], GSTZ1 (glutathione S-transferase zeta 1) [149], NOS1, NOS2 (nitric oxide synthase 1 and 2) [150], and UCPs (uncoupling proteins) $[147,151,152]$ as susceptibility genes.

- Genes involved in telomeres length: they have been found to be associated with human longevity such as TERT and TERC (telomerase reverse transcriptase, telomerase RNA component) [153], SIRT1, and SIRT3 (sirtuins) $[154,155]$. The first discoveries were made in yeasts and tetrahymena by Elizabeth Blackburn, finding the role of TERT and TERC ([156] and references within). In Caenorhabditis elegans over-expressing a protein involved in telomere length regulation leads to the elongation of telomeres and extends the life span, making the organism more resistant to heat stress [157]. The over-expression of TERT also extends the life span of mice [158]. In yeast, sirtuins promote longevity [159]; in particular, it has been reported that Sir2 mediates life-span extension due by calorie restriction [160]. These findings have been replicated in other model organisms [161], but their role in longevity is not consistent for all species, and therefore is still under debate [162].

- Genes involved in metabolism and cellular division: APOE (apolipoprotein E) [163], TXNRD1 (thioredoxin reductase 1), XDH (xanthine dehydrogenase) [163], MAP3K7 (mitogen-activated protein kinase kinase kinase 7) [149], AKT kinase, and TOR [164]. The association of APOE with human longevity have been replicated in different populations: [165-167]. Apolipoprotein $\mathrm{E}$ (apoE) exhibits three isoforms: apoE2, apoE3 and apoE4. They are involved in inflammation, elevated lipid levels, and oxidative stress; furthermore, these are risk factors for cardiovascular disease and Alzheimer's disease, as reported by Huebbe et al. (2011) [168]. APOE2 has been defined as a longevity gene for its putative protective function; it is abundant in long-lived people, while APOE4, that differs from e3 allele at a single aa (112cys), and has been considered a frailty allele [169]. In fact, it increases the risk of Alzheimer's disease and cardiovascular diseases, maybe for a putative interaction with the $\beta$ amyloid protein, and it is almost absent in centenarians.

- Genes belonging to the IGF/GH and insulin pathway: mutations in genes belonging to the insulin or insulin-like signaling pathway extend the life span of Caenorhabditis elegans [170,171], Drosophila melanogaster $[59,109,172]$, and mice $[69,173]$. In humans, it has been observed that insulin sensitivity normally decreases during aging. On the other hand, centenarians are more sensitive to insulin than other people, and often show lower IGF-1 plasma levels [174]. SNP studies have found an association of particular alleles or haplotypes for INS (insulin) [175], INSR (insulin receptor) [176], IGF1 (insulin growth factor 1) [177], IGF1R (insulin growth factor 1 receptor); in fact, a specific haplotype of the IGF-I receptor and the kinase PI3KCB is frequently found in individuals living longer together with low plasma levels of IGF-1 [178], IGF2 (insulin growth factor 2) [179], IGF2R (insulin growth factor 2 receptor) [180], IRS1 (insulin receptor substrate 1) [177], GH1 (growth hormone 1) [177], GHSR (growth hormone secretagogue receptor type 1) [175], FOXO1A (forkhead box protein $\mathrm{O} 1 \mathrm{~A}$ ), and FOXO3A (forkhead box protein $\mathrm{O} 3 \mathrm{~A}$ ) transcription factor, which contains alleles that are associated with longevity in multiple Asian and European populations [181-185].

FOXO is a transcription factor that is conserved in all eukaryotic organisms and is negatively regulated by the insulin-signaling pathway. When insulin or insulin-like growth factor signaling is low, FOXO is activated, and life-span extension occurs [182]. 
Studies on all of the model organisms cited above have thus contributed to the discovery of the fundamental mechanisms of aging in humans. The essential conservation of these mechanisms throughout evolution has been strikingly confirmed in all the model organisms that have been tested so far. The series of similarities found in the mechanisms of regulation of aging in all the model organisms and in humans make us believe that these mechanisms have been preserved during the evolution from yeast to mammals $[36,186]$. For example, the protein sequence of DAF-2 (the C. elegans insulin/IGF receptor ortholog) shows $34 \%$ identity with the IGF-IR of mammals, nematode's AGE-1 is $27 \%$ identical to its ortholog PI3KCB kinase, and DAF-16 is $49 \%$ identical to FOXO1A, while IRS- 1 has 30\% identity with Drosophila's insulin receptor substrate 1 (CHICO). In addition, these factors regulate similar processes in all organisms such as resistance to oxidative stress, metabolism, nutrient utilization, and of course life span [187]. A 2007 study compared genes whose transcription varies with the inhibition of the insulin/IGF-1 pathway in three different species-C. elegans, Drosophila, and mouse - and it was demonstrated that there are significant similarities concerning in particular two main categories of genes. The first one includes genes involved in protein synthesis that are hypoexpressed (this was also independently observed in yeast [188]), the second one includes genes involved in detoxification that are over-expressed, (e.g., the gene coding for glutathione S-transferase [189]). Consistent with the latter observation, the over-expression of transcription factors that regulate xenobiotics metabolism increases survival in Caenorhabditis and Drosophila [190]. The considerable affinities that were found confirm that the mechanism of aging, which is specifically mediated by the insulin-dependent pathway, has been preserved during the evolution in all eukaryotes from yeast to humans. In addition, it has been also confirmed that these pathways may be regulated mainly by nutrients [191]. Calorie restriction, protein restriction, fasting, and a fasting-mimicking diet are in fact becoming interesting alternatives to manipulating our genome structure [192]. Again, it has been so far confirmed that simple model systems, despite their clear morphological differences with humans, can be effectively used as a model to pave the way to future relevant discoveries in humans. Therefore, we believe that model systems will continue to be an essential tool for aging research and for the usage of high-throughput methodologies However, the observation that wild-caught animals may behave differently than lab animals stresses the need to confirm the results obtained with one organism in other species or in wild-caught animals in order to avoid the possibility that lab condition and repeated breeding may have favored genetic drift or epigenetic changes.

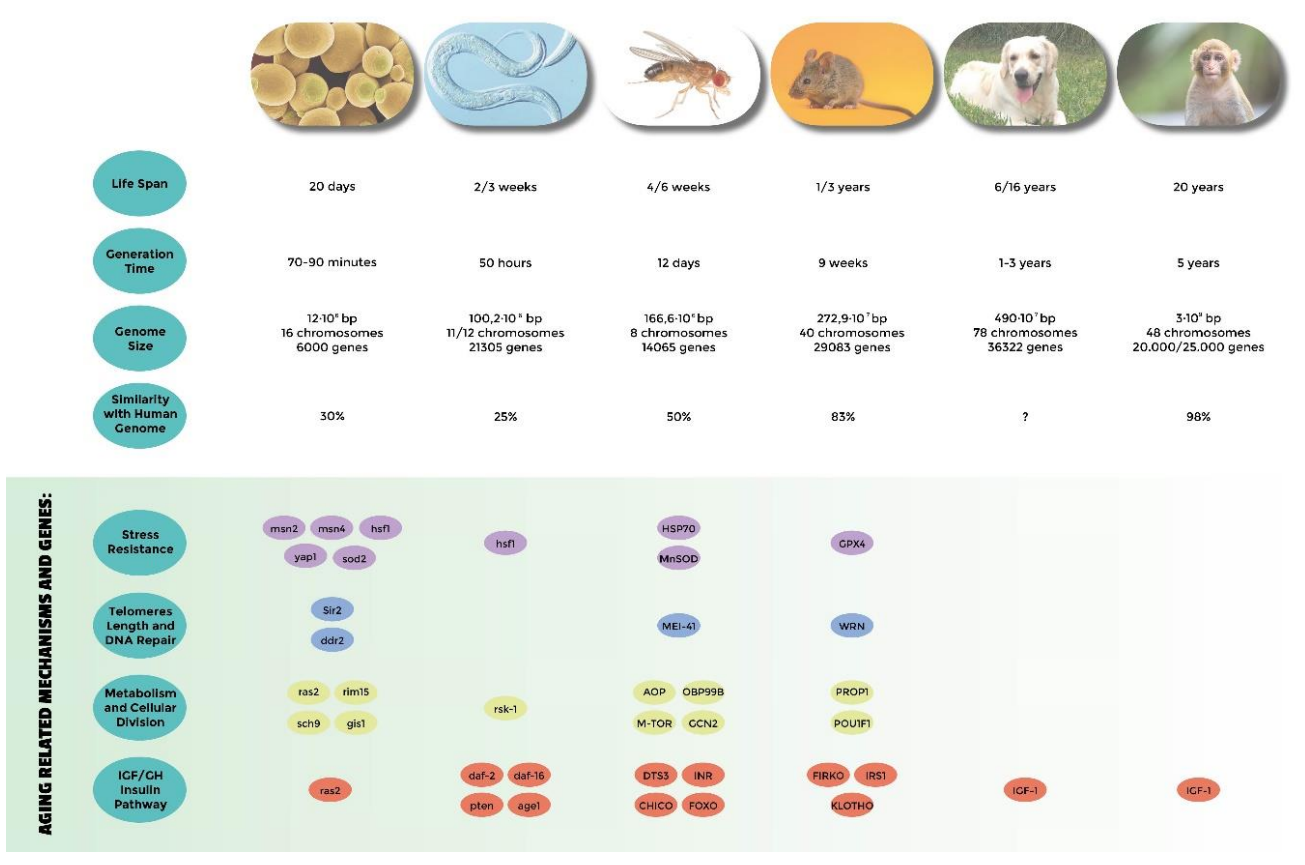

Figure 1. Comparative analysis of the most used model systems in aging research. Genome informations are from NCBI. 
Author Contributions: G.T. wrote the paper; F.F. prepared the figure; S.V., N.G., A.R. revised and made suggestions to improve the paper; M.G.M. conceived, wrote andrevised the paper.

Funding: M.G.M. is funded by Create Cures foundation and The Laurus Project foundation.

Acknowledgments: We would like to thank Valentino Bellini for graphical assistance.

Conflicts of Interest: The authors declare no conflict of interest. The funders had no role in the design of the study; in the collection, analyses, or interpretation of data; in the writing of the manuscript, and in the decision to publish the results.

\section{References}

1. Williams, G.C. Pleiotropy, natural selection, and the evolution of senescence. Evolution 1957, 11, 398. [CrossRef]

2. Longo, V.D.; Finch, C.E. Evolutionary Medicine: From Dwarf Model Systems to Healthy Centenarians? Science 2003, 299, 1342. [CrossRef] [PubMed]

3. Kirkwood, T.B. Understanding the odd science of aging. Cell 2005, 120, 437. [CrossRef] [PubMed]

4. Longo, V.D.; Mitteldorf, J.; Skulachev, V.P. Programmed and altruistic ageing. Nat. Rev. Genet. 2005, 6, 866. [CrossRef] [PubMed]

5. Hartwell, L.H. Nobel Lecture. Yeast and cancer. Biosci. Rep. 2002, 22, 373-394. [CrossRef] [PubMed]

6. Coughlan, C.M.; Brodsky, J.L. Use of yeast as a model system to investigate protein confor-mational diseases. Mol. Biotechnol. 2005, 30, 171-180. [CrossRef]

7. Nakano, A. Yeast Golgi apparatus-Dynamics and sorting. Cell Mol. Life Sci. 2004, 61, 186-191. [CrossRef]

8. Bowers, K.; Stevens, T.H. Protein transport from the late Golgi to the vacuole in the yeast Sac-charomyces cerevisiae. Biochim. Biophys. Acta 2005, 1744, 438-454. [CrossRef]

9. Petranovic, D.; Nielsen, J. Can yeast systems biology contribute to the understanding of human disease? Trends Biotechnol. 2008, 26, 584-590. [CrossRef]

10. Karathia, H.; Vilaprinyo, E.; Sorribas, A.; Alves, R. Saccharomyces cerevisiae as a model or-ganism: A comparative study. PLoS ONE 2011, 6, e16015. [CrossRef]

11. Oliveira, A.V.; Vilaça, R.; Santos, C.N.; Costa, V.; Menezes, R. Exploring the power of yeast to model aging and age-related neurodegenerative disorders. Biogerontology 2017, 18, 3-34. [CrossRef] [PubMed]

12. Mirisola, M.G.; Braun, R.J.; Petranovic, D. Approaches to study yeast cell aging and death. FEMS Yeast Res. 2014, 14, 109-118. [CrossRef] [PubMed]

13. Longo, V.D.; Shadel, G.S.; Kaeberlein, M.; Kennedy, B. Replicative and chronological aging in Saccharomyces cerevisiae. Cell Metab. 2012, 16, 18-31. [CrossRef] [PubMed]

14. Mortimer, R.K.; Johnston, J.R. Life span of individual yeast cells. Nature 1959, 183, 1751-1752. [CrossRef] [PubMed]

15. Hu, J.; Wei, M.; Mirisola, M.G.; Longo, V.D. Assessing chronological aging in Saccharomyces cerevisiae. Methods Mol. Biol. 2013, 965, 463-472. [PubMed]

16. Mirisola, M.G.; Longo, V.D. Acetic acid and acidification accelerate chronological and replicative aging in yeast. Cell Cycle 2012, 11, 3532-3533. [CrossRef] [PubMed]

17. Fabrizio, P.; Gattazzo, C.; Battistella, L.; Wei, M.; Cheng, C.; McGrew, K.; Longo, V.D. Sir2 blocks extreme life-span extension. Cell 2005, 123, 655-667. [CrossRef]

18. Longo, V.D. Mutations in signal transduction proteins increase stress resistance and longevity in yeast, nematodes, fruit flies, and mammalian neuronal cells. Neurobiol. Aging 1999, 20, 479-486. [CrossRef]

19. Longo, V.D.; Gralla, E.B.; Valentine, J.S. Superoxide dismutase activity is essential for sta-tionary phase survival in Saccharomyces cerevisiae. Mitochondrial production of toxic oxygen spe-cies in vivo. J. Biol. Chem. 1996, 271, 12275-12280. [CrossRef]

20. Dhirendra, K.S.; Dwight, V.N.; McCormick, F. RAS Proteins and Their Regulators in Human Disease. Cell 2017, 170, 17-33.

21. Mirisola, M.G.; Seidita, G.; Verrotti, A.C.; Di Blasi, F.; Fasano, O. Mutagenic alteration of the distal switch II region of RAS blocks CDC25-dependent signaling functions. J. Biol. Chem. 1994, 269, 15740-15748. [PubMed]

22. Liu, Y.; Yang, F.; Li, S.; Dai, J.; Deng, H. Glutaredoxin Deletion Shortens Chronological Life Span in Saccharomyces cerevisiae via ROS-Mediated Ras/PKA Activation. J. Proteome Res. 2018, 17, $2318-2327$. [CrossRef] [PubMed] 
23. Pedruzzi, I.; Burckert, N.; Egger, P.; De Virgilio, C. Saccharomyces cerevisiae Ras/cAMP pathway controls post-diauxic shift element-dependent transcription through the zinc finger protein Gis1. EMBO J. 2000, 19, 2569-2579. [CrossRef] [PubMed]

24. Longo, V.D. The Chronological Life Span of Saccharomyces Cerevisiae. Studies of Superoxide Dismutase, Ras and Bcl-2. Ph.D. Thesis, University of California Los Angeles, Westwood, CA, USA, 1997.

25. Wei, M.; Fabrizio, P.; Hu, J.; Ge, H.; Cheng, C.; Li, L.; Longo, V.D. Life span extension by calorie restriction depends on Rim15 and transcription factors downstream of Ras/PKA, Tor, and Sch9. PLoS Genet. 2008, 4, e13. [CrossRef] [PubMed]

26. Martinez-Pastor, M.T.; Marchler, G.; Schuller, C.; Marchler-Bauer, A.; Ruis, H.; Estruch, F. The Saccharomyces cerevisiae zinc finger proteins Msn2p and Msn4p are required for transcriptional induction through the stress response element (STRE). EMBO J. 1996, 15, 2227-2235. [CrossRef]

27. Fabrizio, P.; Pozza, F.; Pletcher, S.D.; Gendron, C.M.; Longo, V.D. Regulation of longevity and stress resistance by Sch9 in yeast. Science 2001, 292, 288-290. [CrossRef]

28. Hu, J.; Wei, M.; Mirzaei, H.; Madia, F.; Mirisola, M.; Amparo, C.; Chagoury, S.; Kennedy, B.; Longo, V.D. Tor-Sch9 deficiency activates catabolism of the ketone body-like acetic acid to promote trehalose accumulation and longevity. Aging Cell 2014, 13, 457-467. [CrossRef]

29. Toda, T.; Cameron, S.; Sass, P.; Wigler, M. SCH9, a gene of Saccharomyces cerevisiae that encodes a protein distinct from, but functionally and structurally related to, cAMP-dependent protein kinase catalytic subunits. Genes Dev. 1988, 2, 517-527. [CrossRef]

30. Thevelein, J.M.; De Winde, J.H. Novel sensing mechanisms and targets for the cAMP-protein kinase A pathway in the yeast Saccharomyces cerevisiae. Mol. Microbiol. 1999, 33, 904-918. [CrossRef]

31. Mirisola, M.G.; Taormina, G.; Fabrizio, P.; Wei, M.; Hu, J.; Longo, V.D. Serine- and threo-nine/valine-dependent activation of PDK and Tor orthologs converge on Sch9 to promote aging. PLoS Genet. 2014, 10, e1004113. [CrossRef]

32. Flattery-O'Brien, J.A.; Grant, C.M.; Dawes, I.W. Stationary-phase regulation of the Saccha-romyces cerevisiaeSOD2 gene is dependent on additive effects of HAP2/3/4/5- and STRE-binding elements. Mol. Microbiol. 1997, 23, 303-312. [CrossRef] [PubMed]

33. Harris, N.; MacLean, M.; Hatzianthis, K.; Panaretou, B.; Piper, P.W. Increasing Saccharomyces cerevisiae stress resistance, through the overactivation of the heat shock response resulting from defects in the Hsp90 chaperone, does not extend replicative life span but can be associated with slower chronological ageing of nondividing cells. Mol. Genet. Genom. 2001, 265, 258-263.

34. Herker, E.; Jungwirth, H.; Lehmann, K.A.; Maldener, C.; Frohlich, K.U.; Wissing, S.; Buttner, S.; Fehr, M.; Sigrist, S.; Madeo, F. Chronological aging leads to apoptosis in yeast. J. Cell Biol. 2004, 164, 501-507. [CrossRef] [PubMed]

35. Longo, V.D. The Ras and Sch9 pathways regulate stress resistance and longevity. Exp. Gerontol. 2003, 38, 807-811. [CrossRef]

36. Fontana, L.; Partridge, L.; Longo, V.D. Extending healthy life span-From yeast to humans. Science 2010, 328, 321-326. [CrossRef] [PubMed]

37. Parrella, E.; Longo, V.D. Insulin/IGF-I and related signaling pathways regulate aging in nondividing cells: From yeast to the mammalian brain. Sci. World J. 2010, 10, 161-177. [CrossRef] [PubMed]

38. Xu, X.; Kim, S.K. The early bird catches the worm: New technologies for the Caenorhabditis elegans toolkit. Nat. Rev. Genet. 2011, 12, 793-801. [CrossRef] [PubMed]

39. Boulin, T.; Hobert, O. From genes to function: The C. elegans genetic toolbox. Wiley Interdiscip. Rev. Dev. Biol. 2012, 1, 114-137. [CrossRef] [PubMed]

40. Lai, C.H.; Chou, C.Y.; Ch'ang, L.Y.; Liu, C.S.; Lin, W. Identification of novel human genes evolutionarily conserved in Caenorhabditis elegans by comparative proteomics. Genome Res. 2000, 10, 703-713. [CrossRef]

41. Calixto, A.; Ma, C.; Chalfie, M. Conditional gene expression and RNAi using MEC-8-dependent splicing in C. elegans. Nat. Methods 2010, 7, 407-411. [CrossRef]

42. Tarkhov, A.E.; Alla, R.; Ayyadevara, S.; Pyatnitskiy, M.; Menshikov, L.I.; Reis, R.J.S.; Fedichev, P.O. A universal transcriptomic signature of age reveals the temporal scaling of Caenorhabditis elegans aging trajectories. Sci. Rep. 2019, 9, 7368. [CrossRef] [PubMed]

43. Son, H.G.; Altintas, O.; Kim, E.J.E.; Kwon, S.; Lee, S.V. Age-dependent changes and biomarkers of aging in Caenorhabditis elegans. Aging Cell 2019, 18, e12853. [CrossRef] [PubMed] 
44. Kenyon, C.; Chang, J.; Gensch, E.; Rudner, A.; Tabtiang, R.A.C. C. elegans mutant that lives twice as long as wild type. Nature 1993, 366, 461-464. [CrossRef] [PubMed]

45. Riddle, D.L.; Albert, P.S. Genetic and Environmental Regulation of Dauer Larva Development. In C. elegans II, 2nd ed.; Riddle, D.L., Blumenthal, T., Meyer, B.J., Priess, J.R., Eds.; Cold Spring Harbor Laboratory Press: New York, NY, USA, 1997.

46. Kimura, K.D.; Tissenbaum, H.A.; Liu, Y.; Ruvkun, G. daf-2, an insulin receptor-like gene that regulates longevity and diapause in Caenorhabditis elegans. Science 1997, 277, 942-946. [CrossRef] [PubMed]

47. Lin, K.; Dorman, J.B.; Rodan, A.; Kenyon, C. daf-16: An HNF-3/forkhead family member that can function to double the life-span of Caenorhabditis elegans. Science 1997, 278, 1319-1322. [CrossRef] [PubMed]

48. Henderson, S.T.; Johnson, T.E. daf-16 integrates developmental and environmental inputs to mediate aging in the nematode Caenorhabditis elegans. Curr. Biol. 2001, 11, 1975-1980. [CrossRef]

49. Lee, R.Y.; Hench, J.; Ruvkun, G. Regulation of C. elegans DAF-16 and its human ortholog FKHRL1 by the daf-2 insulin-like signaling pathway. Curr. Biol. 2001, 11, 1950-1957. [CrossRef]

50. Hesp, K.; Smant, G.; Kammenga, J.E. Caenorhabditis elegans DAF-16/FOXO transcription factor and its mammalian homologs associate with age-related disease. Exp. Gerontol. 2015, 72, 1-7. [CrossRef]

51. Morley, J.F.; Morimoto, R.I. Regulation of longevity in Caenorhabditis elegans by heat shock factor and molecular chaperones. Mol. Biol. Cell 2004, 15, 657-664. [CrossRef]

52. Larsen, P.L.; Albert, P.S.; Riddle, D.L. Genes that regulate both development and longevity in Caenorhabditis elegans. Genetics 1995, 139, 1567-1583.

53. Dorman, J.B.; Albinder, B.; Shroyer, T.; Kenyon, C. The age-1 and daf-2 genes function in a common pathway to control the lifespan of Caenorhabditis elegans. Genetics 1995, 141, 1399-1406. [PubMed]

54. Honda, Y.; Honda, S. Oxidative stress and life span determination in the nematode Caenorhabditis elegans. Ann. N. Y. Acad. Sci. 2002, 959, 466-474. [CrossRef] [PubMed]

55. Branicky, R.; Benard, C.; Hekimi, S. clk-1, mitochondria, and physiological rates. Bioessays 2000, 22, 48-56. [CrossRef]

56. Piper, M.D.W.; Partridge, L. Drosophila as a model for ageing. Biochim. Biophys. Acta Mol. Basis Dis. 2018, 1864, 2707-2717. [CrossRef] [PubMed]

57. Brandt, A.; Vilcinskas, A. The Fruit Fly Drosophila melanogaster as a Model for Aging Research. Adv. Biochem. Eng. Biotechnol. 2013, 135, 63-77. [PubMed]

58. Orr, W.C.; Sohal, R.S. Extension of life-span by overexpression of superoxide dismutase and catalase in Drosophila melanogaster. Science 1994, 263, 1128-1130. [CrossRef]

59. Clancy, D.J.; Gems, D.; Harshman, L.G.; Oldham, S.; Stocker, H.; Hafen, E.; Leevers, S.J.; Partridge, L. Extension of life-span by loss of CHICO, a Drosophila insulin receptor substrate protein. Science 2001, 292, 104-106. [CrossRef]

60. Sun, J.; Tower, J. FLP recombinase-mediated induction of $\mathrm{Cu} / \mathrm{Zn}$-superoxide dismutase transgene expression can extend the life span of adult Drosophila melanogaster flies. Mol. Cell Biol. 1999, 19, 216-228. [CrossRef]

61. Piper, M.D.; Selman, C.; McElwee, J.J.; Partridge, L. Separating cause from effect: How does insulin/IGF signalling control lifespan in worms, flies and mice? J. Intern. Med. 2008, 263, 179-191. [CrossRef]

62. Alic, N.; Giannakou, M.E.; Papatheodorou, I.; Hoddinott, M.P.; Andrews, T.D.; Bolukbasi, E.; Partridge, L. Interplay of dFOXO and two ETS-family transcription factors determines lifespan in Drosophila melanogaster. PLoS Genet. 2014, 10, e1004619. [CrossRef]

63. Kucerova, L.; Kubrak, O.I.; Bengtsson, J.M.; Strnad, H.; Nylin, S.; Theopold, U.; Nassel, D.R. Slowed aging during reproductive dormancy is reflected in genome-wide transcriptome changes in Drosophila melanogaster. BMC Genom. 2016, 17, 50. [CrossRef]

64. Bjedov, I.; Toivonen, J.M.; Kerr, F.; Slack, C.; Jacobson, J.; Foley, A.; Partridge, L. Mechanisms of life span extension by rapamycin in the fruit fly Drosophila melanogaster. Cell Metab. 2010, 11, 35-46. [CrossRef]

65. Kapahi, P.; Zid, B.M.; Harper, T.; Koslover, D.; Sapin, V.; Benzer, S. Regulation of lifespan in Drosophila by modulation of genes in the TOR signaling pathway. Curr. Biol. 2004, 14, 885-890. [CrossRef]

66. Katewa, S.D.; Kapahi, P. Role of TOR signaling in aging and related biological processes in Drosophila melanogaster. Exp. Gerontol. 2011, 46, 382-390. [CrossRef]

67. Ulgherait, M.; Rana, A.; Rera, M.; Graniel, J.; Walker, D.W. AMPK modulates tissue and or-ganismal aging in a non-cell-autonomous manner. Cell Rep. 2014, 8, 1767-1780. [CrossRef] 
68. Chapman, T.; Partridge, L. Female fitness in Drosophila melanogaster: An interaction between the effect of nutrition and of encounter rate with males. Proc. Biol. Sci. 1996, 263, 755-759.

69. Kang, M.J.; Vasudevan, D.; Kang, K.; Kim, K.; Park, J.E.; Zhang, N.; Zeng, X.; Neubert, T.A.; Marr, M.T., 2nd; Ryoo, H.D. 4E-BP is a target of the GCN2-ATF4 pathway during Drosophila development and aging. J. Cell Biol. 2017, 216, 115-129. [CrossRef]

70. Brown-Borg, H.M.; Borg, K.E.; Meliska, C.J.; Bartke, A. Dwarf mice and the ageing process. Nature 1996, 384, 33. [CrossRef]

71. Dolle, M.E.; Snyder, W.K.; Vijg, J. Genotyping the Prop-1 mutation in Ames dwarf mice. Mech. Ageing Dev. 2001, 122, 1915-1918. [CrossRef]

72. Andersen, B.; Pearse, R.V., 2nd; Jenne, K.; Sornson, M.; Lin, S.C.; Bartke, A.; Rosenfeld, M.G. The Ames dwarf gene is required for Pit-1 gene activation. Dev. Biol. 1995, 172, 495-503. [CrossRef]

73. Snell, G.D. Dwarf, a new mendelian recessive character of the house mouse. Proc. Natl. Acad. Sci. USA 1929, 15, 733-734. [CrossRef]

74. Flurkey, K.; Papaconstantinou, J.; Miller, R.A.; Harrison, D.E. Lifespan extension and delayed immune and collagen aging in mutant mice with defects in growth hormone production. Proc. Natl. Acad. Sci. USA 2001, 98, 6736-6741. [CrossRef]

75. Flurkey, K.; Papaconstantinou, J.; Harrison, D.E. The Snell dwarf mutation Pit1(dw) can in-crease life span in mice. Mech. Ageing Dev. 2002, 123, 121-130. [CrossRef]

76. Turyn, D.; Dominici, F.P.; Sotelo, A.I.; Bartke, A. Specific interactions of growth hormone (GH) with GH-receptors and GH-binding proteins in vivo in genetically GH-deficient Ames dwarf mice. Growth Horm. IGF Res. 1998, 8, 389-396. [CrossRef]

77. Bartke, A.; Brown-Borg, H.M.; Bode, A.M.; Carlson, J.; Hunter, W.S.; Bronson, R.T. Does growth hormone prevent or accelerate aging? Exp. Gerontol. 1998, 33, 675-687. [CrossRef]

78. Hunter, W.S.; Croson, W.B.; Bartke, A.; Gentry, M.V.; Meliska, C.J. Low body temperature in long-lived Ames dwarf mice at rest and during stress. Physiol. Behav. 1999, 67, 433-437. [CrossRef]

79. Svare, B.; Bartke, A.; Doherty, P.; Mason, I.; Michael, S.D.; Smith, M.S. Hyperprolactinemia suppresses copulatory behavior in male rats and mice. Biol. Reprod. 1979, 21, 529-535. [CrossRef]

80. Garcia, A.M.; Busuttil, R.A.; Calder, R.B.; Dolle, M.E.; Diaz, V.; McMahan, C.A.; Bartke, A.; Nelson, J.; Reddick, R.; Vijg, J. Effect of Ames dwarfism and caloric restriction on spontaneous DNA mutation frequency in different mouse tissues. Mech. Ageing Dev. 2008, 129, 528-533. [CrossRef]

81. Alderman, J.M.; Flurkey, K.; Brooks, N.L.; Naik, S.B.; Gutierrez, J.M.; Srinivas, U.; Ziara, K.B.; Jing, L.; Boysen, G.; Bronson, R.; et al. Neuroendocrine inhibition of glucose production and resistance to cancer in dwarf mice. Exp. Gerontol. 2009, 44, 26-33. [CrossRef]

82. Brown-Borg, H.; Johnson, W.T.; Rakoczy, S.; Romanick, M. Mitochondrial oxidant gen-eration and oxidative damage in Ames dwarf and GH transgenic mice. J. Am. Aging Assoc. 2001, 24, 85-96.

83. Brown-Borg, H.M.; Bode, A.M.; Bartke, A. Antioxidative mechanisms and plasma growth hormone levels: Potential relationship in the aging process. Endocrine 1999, 11, 41-48. [CrossRef]

84. Brown-Borg, H.M.; Rakoczy, S.G. Catalase expression in delayed and premature aging mouse models. Exp. Gerontol. 2000, 35, 199-212. [CrossRef]

85. Bokov, A.F.; Lindsey, M.L.; Khodr, C.; Sabia, M.R.; Richardson, A. Long-lived ames dwarf mice are resistant to chemical stressors. J. Gerontol. A Biol. Sci. Med. Sci. 2009, 64, 819-827. [CrossRef]

86. Patrick, A.; Seluanov, M.; Hwang, C.; Tam, J.; Khan, T.; Morgenstern, A.; Wiener, L.; Vazquez, J.M.; Zafar, H.; Wen, R.; et al. Sensitivity of primary fibroblasts in culture to atmospheric oxygen does not correlate with species lifespan. Aging 2016, 8, 841-847. [CrossRef]

87. Bluher, M.; Kahn, B.B.; Kahn, C.R. Extended longevity in mice lacking the insulin receptor in adipose tissue. Science 2003, 299, 572-574. [CrossRef]

88. Bartke, A. Minireview: Role of the growth hormone/insulin-like growth factor system in mammalian aging. Endocrinology 2005, 146, 3718-3723. [CrossRef]

89. Selman, C.; Tullet, J.M.; Wieser, D.; Irvine, E.; Lingard, S.J.; Choudhury, A.I.; Claret, M.; Al-Qassab, H.; Carmignac, D.; Ramadani, F.; et al. Ribosomal protein $\mathrm{S} 6$ kinase 1 signaling regulates mammalian life span. Science 2009, 326, 140-144. [CrossRef] 
90. Kuro-o, M.; Matsumura, Y.; Aizawa, H.; Kawaguchi, H.; Suga, T.; Utsugi, T.; Ohyama, Y.; Kurabayashi, M.; Kaname, T.; Kume, E.; et al. Mutation of the mouse klotho gene leads to a syndrome resembling ageing. Nature 1997, 390, 45-51. [CrossRef]

91. Kurosu, H.; Yamamoto, M.; Clark, J.D.; Pastor, J.V.; Nandi, A.; Gurnani, P.; McGuinness, O.P.; Chikuda, H.; Yamaguchi, M.; Kawaguchi, H.; et al. Suppression of aging in mice by the hormone Klotho. Science 2005, 309, 1829-1833. [CrossRef]

92. Bektas, A.; Schurman, S.H.; Sharov, A.A.; Carter, M.G.; Dietz, H.C.; Francomano, C.A. Klotho gene variation and expression in 20 inbred mouse strains. Mamm. Genome 2004, 15, 759-767. [CrossRef]

93. Chang, S. A mouse model of Werner Syndrome: What can it tell us about aging and cancer? Int. J. Biochem. Cell Biol. 2005, 37, 991-999. [CrossRef]

94. Austad, S.N. Comparative biology of aging. J. Gerontol. A Biol. Sci. Med. Sci. 2009, 64, 199-201. [CrossRef]

95. Greer, K.A.; Canterberry, S.C.; Murphy, K.E. Statistical analysis regarding the effects of height and weight on life span of the domestic dog. Res. Vet. Sci. 2007, 82, 208-214. [CrossRef]

96. Bonnett, B.N.; Egenvall, A. Age patterns of disease and death in insured Swedish dogs, cats and horses. J. Comp. Pathol. 2010, 142, S33-S38. [CrossRef]

97. Fleming, J.M.; Creevy, K.E.; Promislow, D.E. Mortality in north american dogs from 1984 to 2004: An investigation into age-, size-, and breed-related causes of death. J. Vet. Intern. Med. 2011, 25, 187-198. [CrossRef]

98. Creevy, K.E.; Austad, S.N.; Hoffman, J.M.; O'Neill, D.G.; Promislow, D.E. The Companion Dog as a Model for the Longevity Dividend. Cold Spring Harb. Perspect. Med. 2016, 6, a026633. [CrossRef]

99. Freeman, L.M. Cachexia and sarcopenia: Emerging syndromes of importance in dogs and cats. J. Vet. Intern. Med. 2012, 26, 3-17. [CrossRef]

100. Urfer, S.R.; Greer, K.; Wolf, N.S. Age-related cataract in dogs: A biomarker for life span and its relation to body size. Age (Dordr) 2011, 33, 451-460. [CrossRef]

101. Vite, C.H.; Head, E. Aging in the canine and feline brain. Vet. Clin. N. Am. Small Anim. Pract. 2014, 44, 1113-1129. [CrossRef]

102. Boyko, A.R.; Quignon, P.; Li, L.; Schoenebeck, J.J.; Degenhardt, J.D.; Lohmueller, K.E.; Zhao, K.; Brisbin, A.; Parker, H.G.; vonHoldt, B.M.; et al. A simple genetic architecture underlies morphological variation in dogs. PLoS Biol. 2010, 8, e1000451. [CrossRef]

103. Vonholdt, B.M.; Pollinger, J.P.; Lohmueller, K.E.; Han, E.; Parker, H.G.; Quignon, P.; De-genhardt, J.D.; Boyko, A.R.; Earl, D.A.; Auton, A.; et al. Genome-wide SNP and haplotype analyses reveal a rich history underlying dog domestication. Nature 2010, 464, 898-902. [CrossRef] [PubMed]

104. Ostrander, E.A.; Wayne, R.K. The canine genome. Genome Res. 2005, 15, 1706-1716. [CrossRef] [PubMed]

105. Gilmore, K.M.; Greer, K.A. Why is the dog an ideal model for aging research? Exp. Gerontol. 2015, 71, 14-20. [CrossRef] [PubMed]

106. Al-Regaiey, K.A.; Masternak, M.M.; Bonkowski, M.; Sun, L.; Bartke, A. Long-lived growth hormone receptor knockout mice: Interaction of reduced insulin-like growth factor i/insulin signaling and caloric restriction. Endocrinology 2005, 146, 851-860. [CrossRef]

107. Eigenmann, J.E.; Amador, A.; Patterson, D.F. Insulin-like growth factor I levels in proportionate dogs, chondrodystrophic dogs and in giant dogs. Acta Endocrinol. (Copenh) 1988, 118, 105-108. [CrossRef]

108. Greer, K.A.; Hughes, L.M.; Masternak, M.M. Connecting serum IGF-1, body size, and age in the domestic dog. Age (Dordr) 2011, 33, 475-483. [CrossRef]

109. Tatar, M.; Bartke, A.; Antebi, A. The endocrine regulation of aging by insulin-like signals. Science 2003, 299, 1346-1351. [CrossRef]

110. Waters, D.J.; Kengeri, S.S.; Clever, B.; Booth, J.A.; Maras, A.H.; Schlittler, D.L.; Hayek, M.G. Exploring mechanisms of sex differences in longevity: Lifetime ovary exposure and exceptional lon-gevity in dogs. Aging Cell 2009, 8, 752-755. [CrossRef]

111. Adams, V.J.; Ceccarelli, K.; Watson, P.; Carmichael, S.; Penell, J.; Morgan, D.M. Evidence of longer life; a cohort of 39 labrador retrievers. Vet. Rec. 2018, 182, 408. [CrossRef]

112. Kealy, R.D.; Lawler, D.F.; Ballam, J.M.; Mantz, S.L.; Biery, D.N.; Greeley, E.H.; Lust, G.; Segre, M.; Smith, G.K.; Stowe, H.D. Effects of diet restriction on life span and age-related changes in dogs. J. Am. Vet. Med. Assoc. 2002, 220, 1315-1320. [CrossRef] 
113. Lawler, D.F.; Larson, B.T.; Ballam, J.M.; Smith, G.K.; Biery, D.N.; Evans, R.H.; Greeley, E.H.; Segre, M.; Stowe, H.D.; Kealy, R.D. Diet restriction and ageing in the dog: Major observations over two decades. Br. J. Nutr. 2008, 99, 793-805. [CrossRef]

114. Richards, S.E.; Wang, Y.; Claus, S.P.; Lawler, D.; Kochhar, S.; Holmes, E.; Nicholson, J.K. Metabolic phenotype modulation by caloric restriction in a lifelong dog study. J. Proteome Res. 2013, 12, 3117-3127. [CrossRef]

115. Greeley, E.H.; Spitznagel, E.; Lawler, D.F.; Kealy, R.D.; Segre, M. Modulation of canine im-munosenescence by life-long caloric restriction. Vet. Immunol. Immunopathol. 2006, 111, 287-299. [CrossRef]

116. Jimenez, A.G.; Winward, J.; Beattie, U.; Cipolli, W. Cellular metabolism and oxidative stress as a possible determinant for longevity in small breed and large breed dogs. PLoS ONE 2018, 13, e0195832. [CrossRef]

117. Alexander, J.E.; Colyer, A.; Haydock, R.M.; Hayek, M.G.; Park, J. Understanding How Dogs Age: Longitudinal Analysis of Markers of Inflammation, Immune Function, and Oxidative Stress. J. Gerontol. A Biol. Sci. Med. Sci. 2018, 73, 720-728. [CrossRef]

118. Gibbs, R.A.; Rogers, J.; Katze, M.G.; Bumgarner, R.; Weinstock, G.M.; Mardis, E.R.; Remington, K.A.; Strausberg, R.L.; Venter, J.C.; Wilson, R.K.; et al. Evolutionary and biomedical insights from the rhesus macaque genome. Science 2007, 316, 222-234.

119. Zimin, A.V.; Cornish, A.S.; Maudhoo, M.D.; Gibbs, R.M.; Zhang, X.; Pandey, S.; Meehan, D.T.; Wipfler, K.; Bosinger, S.E.; Johnson, Z.P.; et al. A new rhesus macaque assembly and annotation for next-generation sequencing analyses. Biol. Direct 2014, 9, 20. [CrossRef]

120. Yates, A.; Akanni, W.; Amode, M.R.; Barrell, D.; Billis, K.; Carvalho-Silva, D.; Cummins, C.; Clapham, P.; Fitzgerald, S.; Gil, L.; et al. Ensembl 2016. Nucleic Acids Res. 2016, 44, D710-D716. [CrossRef]

121. Chimpanzee Sequencing and Analysis Consortium. Initial sequence of the chimpanzee genome and comparison with the human genome. Nature 2005, 437, 69-87. [CrossRef]

122. Colman, R.J. Non-human primates as a model for aging. Biochim. Biophys. Acta Mol. Basis Dis. 2018, 1864, 2733-2741. [CrossRef]

123. Uno, H. Age-related pathology and biosenescent markers in captive rhesus macaques. Age (Omaha) 1997, 20, 1-13. [CrossRef]

124. Colman, R.J.; McKiernan, S.H.; Aiken, J.M.; Weindruch, R. Muscle mass loss in Rhesus monkeys: Age of onset. Exp. Gerontol. 2005, 40, 573-581. [CrossRef]

125. Colman, R.J.; Kemnitz, J.W.; Lane, M.A.; Abbott, D.H.; Binkley, N. Skeletal effects of aging and menopausal status in female rhesus macaques. J. Clin. Endocrinol. Metab. 1999, 84, 4144-4148. [CrossRef]

126. Bodkin, N.L.; Alexander, T.M.; Ortmeyer, H.K.; Johnson, E.; Hansen, B.C. Mortality and morbidity in laboratory-maintained Rhesus monkeys and effects of long-term dietary restriction. J. Gerontol. A Biol. Sci. Med. Sci. 2003, 58, 212-219. [CrossRef]

127. Mattison, J.A.; Roth, G.S.; Beasley, T.M.; Tilmont, E.M.; Handy, A.M.; Herbert, R.L.; Longo, D.L.; Allison, D.B.; Young, J.E.; Bryant, M.; et al. Impact of caloric restriction on health and survival in rhesus monkeys from the NIA study. Nature 2012, 489, 318-321. [CrossRef]

128. Ramsey, J.J.; Colman, R.J.; Binkley, N.C.; Christensen, J.D.; Gresl, T.A.; Kemnitz, J.W.; Weindruch, R. Dietary restriction and aging in rhesus monkeys: The University of Wisconsin study. Exp. Gerontol. 2000, 35, 1131-1149. [CrossRef]

129. Colman, R.J.; Anderson, R.M.; Johnson, S.C.; Kastman, E.K.; Kosmatka, K.J.; Beasley, T.M.; Allison, D.B.; Cruzen, C.; Simmons, H.A.; Kemnitz, J.W.; et al. Caloric restriction delays disease onset and mortality in rhesus monkeys. Science 2009, 325, 201-204. [CrossRef]

130. Colman, R.J.; Beasley, T.M.; Kemnitz, J.W.; Johnson, S.C.; Weindruch, R.; Anderson, R.M. Caloric restriction reduces age-related and all-cause mortality in rhesus monkeys. Nat. Commun. 2014, 5, 3557. [CrossRef]

131. Mattison, J.A.; Colman, R.J.; Beasley, T.M.; Allison, D.B.; Kemnitz, J.W.; Roth, G.S.; Ingram, D.K.; Weindruch, R.; De Cabo, R.; Anderson, R.M. Caloric restriction improves health and survival of rhesus monkeys. Nat. Commun. 2017, 8, 14063. [CrossRef]

132. Vaughan, K.L.; Kaiser, T.; Peaden, R.; Anson, R.M.; De Cabo, R.; Mattison, J.A. Caloric Re-striction Study Design Limitations in Rodent and Nonhuman Primate Studies. J. Gerontol. A Biol. Sci. Med. Sci. 2017, 73, 48-53. [CrossRef]

133. De Magalhaes, J.P.; Church, G.M. Analyses of human-chimpanzee orthologous gene pairs to explore evolutionary hypotheses of aging. Mech. Ageing Dev. 2007, 128, 355-364. [CrossRef] [PubMed] 
134. Blalock, E.M.; Grondin, R.; Chen, K.C.; Thibault, O.; Thibault, V.; Pandya, J.D.; Dowling, A.; Zhang, Z.; Sullivan, P.; Porter, N.M.; et al. Aging-related gene expression in hippocampus proper compared with dentate gyrus is selectively associated with metabolic syndrome variables in rhesus monkeys. J. NeuroSci. 2010, 30, 6058-6071. [CrossRef] [PubMed]

135. Han, Y.; Han, D.; Yan, Z.; Boyd-Kirkup, J.D.; Green, C.D.; Khaitovich, P.; Han, J.D. Stress-associated H3K4 methylation accumulates during postnatal development and aging of rhesus ma-caque brain. Aging Cell 2012, 11, 1055-1064. [CrossRef] [PubMed]

136. Mohan, M.; Kumar, V.; Lackner, A.A.; Alvarez, X. Dysregulated miR-34a-SIRT1-acetyl p65 axis is a potential mediator of immune activation in the colon during chronic simian immunodeficiency virus infection of rhesus macaques. J. Immunol. 2015, 194, 291-306. [CrossRef] [PubMed]

137. Taormina, G.; Mirisola, M.G. Longevity: Epigenetic and biomolecular aspects. BioMol. Concepts 2015, 6, 105-117. [CrossRef] [PubMed]

138. Paolisso, G.; Tagliamonte, M.R.; Rizzo, M.R.; Manzella, D.; Gambardella, A.; Varricchio, M. Oxidative stress and advancing age: Results in healthy centenarians. J. Am. Geriatr. Soc. 1998, 46, 833-838. [CrossRef]

139. Mecocci, P.; Polidori, M.C.; Troiano, L.; Cherubini, A.; Cecchetti, R.; Pini, G.; Straatman, M.; Monti, D.; Stahl, W.; Sies, H.; et al. Plasma antioxidants and longevity: A study on healthy centenarians. Free Radic. Biol. Med. 2000, 28, 1243-1248. [CrossRef]

140. Di Pietro, F.; Dato, S.; Carpi, F.M.; Corneveaux, J.J.; Serfaustini, S.; Maoloni, S.; Mignini, F.; Huentelman, M.J.; Passarino, G.; Napolioni, V. TP53*P72 allele influences negatively female life expectancy in a population of central Italy: Cross-sectional study and genetic-demographic approach analysis. J. Gerontol. A Biol. Sci. Med. Sci. 2013, 68, 539-545. [CrossRef]

141. Van Heemst, D.; Mooijaart, S.P.; Beekman, M.; Schreuder, J.; De Craen, A.J.; Brandt, B.W.; Slagboom, P.E.; Westendorp, R.G. Variation in the human TP53 gene affects old age survival and cancer mortality. Exp. Gerontol. 2005, 40, 11-15. [CrossRef]

142. Altilia, S.; Santoro, A.; Malagoli, D.; Lanzarini, C.; Álvarez, J.A.B.; Galazzo, G.; Porter, D.C.; Crocco, P.; Rose, G.; Passarino, G.; et al. TP53 codon 72 polymorphism affects accumulation of mtDNA damage in human cells. Aging 2012, 4, 28-39. [CrossRef]

143. Nebel, A.; Flachsbart, F.; Till, A.; Caliebe, A.; Blanché, H.; Arlt, A.; Häsler, R.; Jacobs, G.; Kleindorp, R.; Franke, A.; et al. A functional EXO1 promoter variant is associated with prolonged life expectancy in centenarians. Mech. Ageing Dev. 2009, 130, 691-699. [CrossRef]

144. Soerensen, M.; Christensen, K.; Stevnsner, T.; Christiansen, L. The Mn-superoxide dismutase single nucleotide polymorphism rs4880 and the glutathione peroxidase 1 single nucleotide poly-morphism rs1050450 are associated with aging and longevity in the oldest old. Mech. Ageing Dev. 2009, 130, 308-314. [CrossRef]

145. Lunetta, K.L.; D’Agostino, R.B., Sr.; Karasik, D.; Benjamin, E.J.; Guo, C.Y.; Govindaraju, R.; Kiel, D.P.; Kelly-Hayes, M.; Massaro, J.M.; Pencina, M.J.; et al. Genetic correlates of longevity and selected age-related phenotypes: A genome-wide association study in the Framingham Study. BMC Med. Genet. 2007, 8, S13. [CrossRef]

146. Singh, R.; Kolvraa, S.; Bross, P.; Christensen, K.; Gregersen, N.; Tan, Q.; Jensen, U.B.; Eiberg, H.; Rattan, S.I. Heat-shock protein 70 genes and human longevity: A view from Denmark. Ann. N. Y. Acad. Sci. 2006, 1067, 301-308. [CrossRef]

147. Ross, O.A.; Curran, M.D.; Crum, K.A.; Rea, I.M.; Barnett, Y.A.; Middleton, D. Increased frequency of the 2437T allele of the heat shock protein 70-Hom gene in an aged Irish population. Exp. Gerontol. 2003, 38, 561-565. [CrossRef]

148. Altomare, K.; Greco, V.; Bellizzi, D.; Berardelli, M.; Dato, S.; DeRango, F.; Garasto, S.; Rose, G.; Feraco, E.; Mari, V.; et al. The allele (A)(-110) in the promoter region of the HSP70-1 gene is unfavorable to longevity in women. Biogerontology 2003, 4, 215-220. [CrossRef]

149. Di Cianni, F.; Campa, D.; Tallaro, F.; Rizzato, C.; De Rango, F.; Barale, R.; Passarino, G.; Canzian, F.; Gemignani, F.; Montesanto, A.; et al. MAP3K7 and GSTZ1 are associated with human longevity: A two-stage case-control study using a multilocus genotyping. Age (Dordr) 2013, 35, 1357-1366. [CrossRef]

150. Montesanto, A.; Crocco, P.; Tallaro, F.; Pisani, F.; Mazzei, B.; Mari, V.; Corsonello, A.; Lattanzio, F.; Passarino, G.; Rose, G. Common polymorphisms in nitric oxide synthase (NOS) genes influence quality of aging and longevity in humans. Biogerontology 2013, 14, 177-186. [CrossRef] 
151. Rose, G.; Crocco, P.; De Rango, F.; Montesanto, A.; Passarino, G. Further support to the un-coupling-to-survive theory: The genetic variation of human UCP genes is associated with longevity. PLoS ONE 2011, 6, e29650. [CrossRef]

152. Crocco, P.; Montesanto, A.; Passarino, G.; Rose, G. A common polymorphism in the UCP3 promoter influences hand grip strength in elderly people. Biogerontology 2011, 12, 265-271. [CrossRef]

153. Soerensen, M.; Thinggaard, M.; Nygaard, M.; Dato, S.; Tan, Q.; Hjelmborg, J.; Andersen-Ranberg, K.; Stevnsner, T.; Bohr, V.A.; Kimura, M.; et al. Genetic variation in TERT and TERC and human leukocyte telomere length and longevity: A cross-sectional and longitudinal analysis. Aging Cell 2012, 11, 223-227. [CrossRef]

154. Kim, S.; Bi, X.; Czarny-Ratajczak, M.; Dai, J.; Welsh, D.A.; Myers, L.; Welsch, M.A.; Cherry, K.E.; Arnold, J.; Poon, L.W.; et al. Telomere maintenance genes SIRT1 and XRCC6 impact age-related decline in telomere length but only SIRT1 is associated with human longevity. Bi-ogerontology 2012, 13, 119-131. [CrossRef]

155. Atzmon, G.; Cho, M.; Cawthon, R.M.; Budagov, T.; Katz, M.; Yang, X.; Siegel, G.; Bergman, A.; Huffman, D.M.; Schechter, C.B.; et al. Evolution in health and medicine Sackler colloquium: Genetic variation in human telomerase is associated with telomere length in Ashkenazi centenarians. Proc. Natl. Acad. Sci. USA 2010, 107, 1710-1717. [CrossRef]

156. Blackburn, E.H.; Greider, C.W.; Szostak, J.W. Telomeres and telomerase: The path from maize, Tetrahymena and yeast to human cancer and aging. Nat. Med. 2006, 12, 1133-1138. [CrossRef]

157. Joeng, K.S.; Song, E.J.; Lee, K.J.; Lee, J. Long lifespan in worms with long telomeric DNA. Nat. Genet. 2004, 36, 607-611. [CrossRef]

158. Tomas-Loba, A.; Flores, I.; Fernandez-Marcos, P.J.; Cayuela, M.L.; Maraver, A.; Tejera, A.; Borras, C.; Matheu, A.; Klatt, P.; Flores, J.M.; et al. Telomerase reverse transcriptase delays aging in cancer-resistant mice. Cell 2008, 135, 609-622. [CrossRef]

159. Kaeberlein, M.; McVey, M.; Guarente, L. The SIR2/3/4 complex and SIR2 alone promote longevity in Saccharomyces cerevisiae by two different mechanisms. Genes Dev. 1999, 13, 2570-2580. [CrossRef]

160. Lin, S.J.; Defossez, P.A.; Guarente, L. Requirement of NAD and SIR2 for life-span extension by calorie restriction in Saccharomyces cerevisiae. Science 2000, 289, 2126-2128. [CrossRef]

161. Tissenbaum, H.A.; Guarente, L. Increased dosage of a sir-2 gene extends lifespan in Caeno-rhabditis elegans. Nature 2001, 410, 227-230. [CrossRef]

162. Park, S.; Mori, R.; Shimokawa, I. Do sirtuins promote mammalian longevity? A critical review on its relevance to the longevity effect induced by calorie restriction. Mol. Cells 2013, 35, 474-480. [CrossRef]

163. Soerensen, M.; Dato, S.; Tan, Q.; Thinggaard, M.; Kleindorp, R.; Beekman, M.; Suchiman, H.E.; Jacobsen, R.; McGue, M.; Stevnsner, T.; et al. Evidence from case-control and longitudinal studies supports associations of genetic variation in APOE, CETP, and IL6 with human longevity. Age (Dordr) 2013, 35, 487-500. [CrossRef]

164. Johnson, S.C.; Rabinovitch, P.S.; Kaeberlein, M. mTOR is a key modulator of ageing and age-related disease. Nature 2013, 493, 338-345. [CrossRef]

165. Corder, E.H.; Saunders, A.M.; Strittmatter, W.J.; Schmechel, D.E.; Gaskell, P.C.; Small, G.W.; Roses, A.D.; Haines, J.L.; Pericak-Vance, M.A. Gene dose of apolipoprotein E type 4 allele and the risk of Alzheimer's disease in late onset families. Science 1993, 261, 921-923. [CrossRef] [PubMed]

166. Kervinen, K.; Savolainen, M.J.; Salokannel, J.; Hynninen, A.; Heikkinen, J.; Ehnholm, C.; Koistinen, M.J.; Kesaniemi, Y.A. Apolipoprotein E and B polymorphisms-Longevity factors assessed in nonagenarians. Atherosclerosis 1994, 105, 89-95. [CrossRef]

167. Schachter, F.; Faure-Delanef, L.; Guenot, F.; Rouger, H.; Froguel, P.; Lesueur-Ginot, L.; Cohen, D. Genetic associations with human longevity at the APOE and ACE loci. Nat. Genet. 1994, 6, $29-32$. [CrossRef] [PubMed]

168. Huebbe, P.; Nebel, A.; Siegert, S.; Moehring, J.; Boesch-Saadatmandi, C.; Most, E.; Pallauf, J.; Egert, S.; Muller, M.J.; Schreiber, S.; et al. APOE epsilon4 is associated with higher vitamin D levels in targeted replacement mice and humans. FASEB J. 2011, 25, 3262-3270. [CrossRef] [PubMed]

169. Gerdes, L.U.; Jeune, B.; Ranberg, K.A.; Nybo, H.; Vaupel, J.W. Estimation of apolipoprotein E genotype-specific relative mortality risks from the distribution of genotypes in centenarians and middle-aged men: Apolipoprotein E gene is a "frailty gene," not a "longevity gene". Genet. Epidemiol. 2000, 19, 202-210. [CrossRef] 
170. Vanfleteren, J.R.; Braeckman, B.P. Mechanisms of life span determination in Caenorhabditis elegans. Neurobiol. Aging 1999, 20, 487-502. [CrossRef]

171. Murakami, S.; Johnson, T.E. A genetic pathway conferring life extension and resistance to UV stress in Caenorhabditis elegans. Genetics 1996, 143, 1207-1218.

172. Tatar, M.; Kopelman, A.; Epstein, D.; Tu, M.P.; Yin, C.M.; Garofalo, R.S. A mutant Drosophila insulin receptor homolog that extends life-span and impairs neuroendocrine function. Science 2001, 292, 107-110. [CrossRef]

173. Steger, R.W.; Bartke, A.; Cecim, M. Premature ageing in transgenic mice expressing different growth hormone genes. J. Reprod. Fertil. Suppl. 1993, 46, 61-75.

174. Paolisso, G.; Gambardella, A.; Ammendola, S.; D'Amore, A.; Balbi, V.; Varricchio, M.; D'Onofrio, F. Glucose tolerance and insulin action in healthy centenarians. Am. J. Physiol. 1996, 270, E890-E894.

175. Soerensen, M.; Dato, S.; Tan, Q.; Thinggaard, M.; Kleindorp, R.; Beekman, M.; Jacobsen, R.; Suchiman, H.E.; De Craen, A.J.; Westendorp, R.G.; et al. Human longevity and variation in GH/IGF-1/insulin signaling, DNA damage signaling and repair and pro/antioxidant pathway genes: Cross sectional and longitudinal studies. Exp. Gerontol. 2012, 47, 379-387. [CrossRef]

176. Kojima, T.; Kamei, H.; Aizu, T.; Arai, Y.; Takayama, M.; Nakazawa, S.; Ebihara, Y.; Inagaki, H.; Masui, Y.; Gondo, Y.; et al. Association analysis between longevity in the Japanese population and polymorphic variants of genes involved in insulin and insulin-like growth factor 1 signaling pathways. Exp. Gerontol. 2004, 39, 1595-1598. [CrossRef]

177. Van Heemst, D.; Beekman, M.; Mooijaart, S.P.; Heijmans, B.T.; Brandt, B.W.; Zwaan, B.J.; Slagboom, P.E.; Westendorp, R.G. Reduced insulin/IGF-1 signalling and human longevity. Aging Cell 2005, 4, 79-85. [CrossRef]

178. Bonafe, M.; Barbieri, M.; Marchegiani, F.; Olivieri, F.; Ragno, E.; Giampieri, C.; Mugianesi, E.; Centurelli, M.; Franceschi, C.; Paolisso, G. Polymorphic variants of insulin-like growth factor I (IGF-I) receptor and phosphoinositide 3-kinase genes affect IGF-I plasma levels and human longevity: Cues for an evolutionarily conserved mechanism of life span control. J. Clin. Endocrinol. Metab. 2003, 88, 3299-3304. [CrossRef]

179. Stessman, J.; Maaravi, Y.; Hammerman-Rozenberg, R.; Cohen, A.; Nemanov, L.; Gritsenko, I.; Gruberman, N.; Ebstein, R.P. Candidate genes associated with ageing and life expectancy in the Jerusalem longitudinal study. Mech. Ageing Dev. 2005, 126, 333-339. [CrossRef]

180. Rose, G.; Crocco, P.; D'Aquila, P.; Montesanto, A.; Bellizzi, D.; Passarino, G. Two variants lo-cated in the upstream enhancer region of human UCP1 gene affect gene expression and are correlated with human longevity. Exp. Gerontol. 2011, 46, 897-904. [CrossRef]

181. Li, Y.; Wang, W.J.; Cao, H.; Lu, J.; Wu, C.; Hu, F.Y.; Guo, J.; Zhao, L.; Yang, F.; Zhang, Y.X.; et al. Genetic association of FOXO1A and FOXO3A with longevity trait in Han Chinese populations. Hum. Mol. Genet. 2009, 18, 4897-4904. [CrossRef]

182. Willcox, B.J.; Donlon, T.A.; He, Q.; Chen, R.; Grove, J.S.; Yano, K.; Masaki, K.H.; Willcox, D.C.; Rodriguez, B.; Curb, J.D. FOXO3A genotype is strongly associated with human longevity. Proc. Natl. Acad. Sci. USA 2008, 105, 13987-13992. [CrossRef]

183. Anselmi, C.V.; Malovini, A.; Roncarati, R.; Novelli, V.; Villa, F.; Condorelli, G.; Bellazzi, R.; Puca, A.A. Association of the FOXO3A locus with extreme longevity in a southern Italian centenar-ian study. Rejuvenation Res. 2009, 12, 95-104. [CrossRef] [PubMed]

184. Flachsbart, F.; Caliebe, A.; Kleindorp, R.; Blanche, H.; Von Eller-Eberstein, H.; Nikolaus, S.; Schreiber, S.; Nebel, A. Association of FOXO3A variation with human longevity confirmed in German centenarians. Proc. Natl. Acad. Sci. USA 2009, 106, 2700-2705. [CrossRef] [PubMed]

185. Soerensen, M.; Dato, S.; Christensen, K.; McGue, M.; Stevnsner, T.; Bohr, V.A.; Christiansen, L. Replication of an association of variation in the FOXO3A gene with human longevity using both case-control and longitudinal data. Aging Cell 2010, 9, 1010-1017. [CrossRef] [PubMed]

186. Barbieri, M.; Bonafe, M.; Franceschi, C.; Paolisso, G. Insulin/IGF-I-signaling pathway: An evo-lutionarily conserved mechanism of longevity from yeast to humans. Am. J. Physiol. Endocrinol. Metab. 2003, 285, E1064-E1071. [CrossRef] [PubMed]

187. Giannattasio, S.; Mirisola, M.G.; Mazzoni, C. Cell Stress, Metabolic Reprogramming, and Cancer. Front. Oncol. 2018, 8, 236. [CrossRef] [PubMed]

188. Kaeberlein, M.; Powers, R.W., 3rd; Steffen, K.K.; Westman, E.A.; Hu, D.; Dang, N.; Kerr, E.O.; Kirkland, K.T.; Fields, S.; Kennedy, B.K. Regulation of yeast replicative life span by TOR and Sch9 in response to nutrients. Science 2005, 310, 1193-1196. [CrossRef] [PubMed] 
189. McElwee, J.J.; Schuster, E.; Blanc, E.; Piper, M.D.; Thomas, J.H.; Patel, D.S.; Selman, C.; Withers, D.J.; Thornton, J.M.; Partridge, L.; et al. Evolutionary conservation of regulated lon-gevity assurance mechanisms. Genome Biol. 2007, 8, R132. [CrossRef] [PubMed]

190. Tullet, J.M.; Hertweck, M.; An, J.H.; Baker, J.; Hwang, J.Y.; Liu, S.; Oliveira, R.P.; Baumeister, R.; Blackwell, T.K. Direct inhibition of the longevity-promoting factor SKN-1 by insulin-like signaling in C. elegans. Cell 2008, 132, 1025-1038. [CrossRef] [PubMed]

191. Taormina, G.; Mirisola, M.G. Calorie restriction in mammals and simple model organisms. BioMed Res. Int. 2014, 2014, 308690. [CrossRef] [PubMed]

192. Levine, M.E.; Suarez, J.A.; Brandhorst, S.; Balasubramanian, P.; Cheng, C.W.; Madia, F.; Fontana, L.; Mirisola, M.G.; Guevara-Aguirre, J.; Wan, J.; et al. Low protein intake is associated with a major reduction in IGF-1, cancer, and overall mortality in the 65 and younger but not older population. Cell Metab. 2014, 19, 407-417. [CrossRef] [PubMed]

(C) 2019 by the authors. Licensee MDPI, Basel, Switzerland. This article is an open access article distributed under the terms and conditions of the Creative Commons Attribution (CC BY) license (http://creativecommons.org/licenses/by/4.0/). 